\title{
Determination of Vitamin $D_{3}$ and 25-Hydroxyvitamin $D_{3}$ in Sera by Column-Switching High Performance Liquid Chromatography with Fluorescence Detection
}

\author{
Tetsuharu Iwata*, Masatoshi Yamaguchi*, Hiroshi Hanazono*, Yuki Imazato*, \\ Masaru NAKaMURA* and Yosuke OHKURA** \\ *Faculty of Pharmaceutical Sciences, Fukuoka University, Nanakuma, Fukuoka 814-01, Japan \\ **Faculty of Pharmaceutical Sciences, Kyushu University 62, Maidashi, Fukuoka 812, Japan
}

\begin{abstract}
A column-switching high performance liquid chromatographic method with fluorescence detection for the determination of vitamin $D_{3}$ and 25 -hydroxyvitamin $D_{3}$ in human and rat sera is described. The vitamins in a lipid extract from serum, obtained by solid-phase extraction technique using a Bond-Elut $\mathrm{C}_{18}$ cartridge, are converted with 3,4-dihydro-6,7-dimethoxy-4-methyl-3-oxoquinoxaline-2-carbonyl azide into the corresponding fluorescent derivatives. The derivatives are separated from endogenous interfering substances by column-switching chromatography. The chromatographic system consisted of a precolumn chromatography for clean-up of the derivatives and an analytical column chromatography for the complete separation of the derivatives. The derivatives are detected fluorometrically at excitation and emission wavelengths of 360 and $440 \mathrm{~nm}$, respectively. The detection limits $(S / N=3)$ for vitamin $D_{3}$ and 25-hydroxyvitamin $D_{3}$ are 15 and $8 \mathrm{fmol}$, respectively, in a $10 \mu l$ injection volume. The sensitivity permits simultaneous determination of the vitamins in $1 \mathrm{ml}$ of normal human and rat sera.
\end{abstract}

Keywords Vitamin $D_{3}$, 25-hydroxyvitamin $D_{3}$, column-switching high performance liquid chromatography, fluorescence detection, 3,4-dihydro-6,7-dimethoxy-4-methyl-3-oxoquinoxaline-2-carbonyl azide, human serum, rat serum

Vitamin $D_{3}$ is hydroxylated in the liver to 25 hydroxyvitamin $\mathrm{D}_{3}\left(25-\mathrm{OHD}_{3}\right)$, which is further hydroxylated in the kidney either to $1 \alpha, 25$-dihydroxyvitamin $\mathrm{D}_{3}$ or to 24,25 -dihydroxyvitamin $\mathrm{D}_{3}$. The determination of these compounds in human plasma/serum is very important for the assessment of "vitamin $D_{3}$ status" in healthy and diseased persons. Among these compounds, vitamin $\mathrm{D}_{3}$ and $25-\mathrm{OHD}_{3}$ occur in serum at relatively high concentrations. Thus, their determination is still widely used for the assessment of vitamin $D_{3}$ status and provides significant results in many clinical situations.

Various methods for the determination of vitamin $D_{3}$ and/or $25-\mathrm{OHD}_{3}$ in human plasma/serum have been reported. ${ }^{1-22}$ The methods include lipid extraction, purification by chromatography and quantification by physicochemical methods such as UV-absorption ${ }^{1-14}$ and mass fragmentography ${ }^{15}$, competitive protein binding assays ${ }^{8-14,17-22}$ or radioimmunoassay. ${ }^{14}$ Among these methods, the UV-high performance liquid chromatographic (HPLC) methods have been widely used for the simultaneous determination of vitamin $D_{3}$ and $25-\mathrm{OHD}_{3}$ in plasma/serum. Such methods, however, include an extremely complicated pretreatment of plasma/serum, and require a very long time for the determination.
We have developed 3,4-dihydro-6,7-dimethoxy-4-methyl-3-oxoquinoxaline-2-carbonyl azide (DMEQ- $\mathrm{CON}_{3}$ ) as a highly sensitive and reactive fluorescence derivatization reagent for alcohols. ${ }^{23}$ The reagent has then been applied to the determination of cholesterol and cholestanol in human serum ${ }^{24,25}$, and 7-dehydrocholesterol (previtamin $\mathrm{D}_{3}$ ) in rat $^{26}$ and human skin surfaces. ${ }^{27}$ Recently, we found that vitamin $\mathrm{D}_{3}$ and $25-\mathrm{OHD}_{3}$ react with DMEQ-CON $\mathrm{N}_{3}$ to give the corresponding highly fluorescent carbamic acid esters. This research aims to establish a sensitive column-switching HPLC method utilizing DMEQ-CON ${ }_{3}$ for the simultaneous determination of vitamin $\mathrm{D}_{3}$ and $25-\mathrm{OHD}_{3}$ in human and rat sera.

\section{Experimental}

\section{Chemicals and solutions}

Unless stated otherwise, all chemicals and solvents were of reagent grade. Deionized and distilled water was used. Vitamin $D_{3}$ and its hydroxyl derivatives were purchased from Sigma Chemical Co. (St. Louis, MO, USA). DMEQ-CON ${ }_{3}$ was prepared as described previously. ${ }^{23}$ DMEQ-CON ${ }_{3}$ solution $(2.0 \mathrm{mM})$ was prepared in benzene. The solution could be used for 
two days when stored at $4^{\circ} \mathrm{C}$ in the dark.

Bond-Elut $\mathrm{C}_{18}$ cartridges were obtained from Analytichem International (Harbor City, CA, USA). The cartridges were washed successively with hexane $(2 \mathrm{ml})$, isopropanol $(3 \mathrm{ml})$, methanol $(3 \mathrm{ml})$ and water $(5 \mathrm{ml})$ before use. ${ }^{6}$

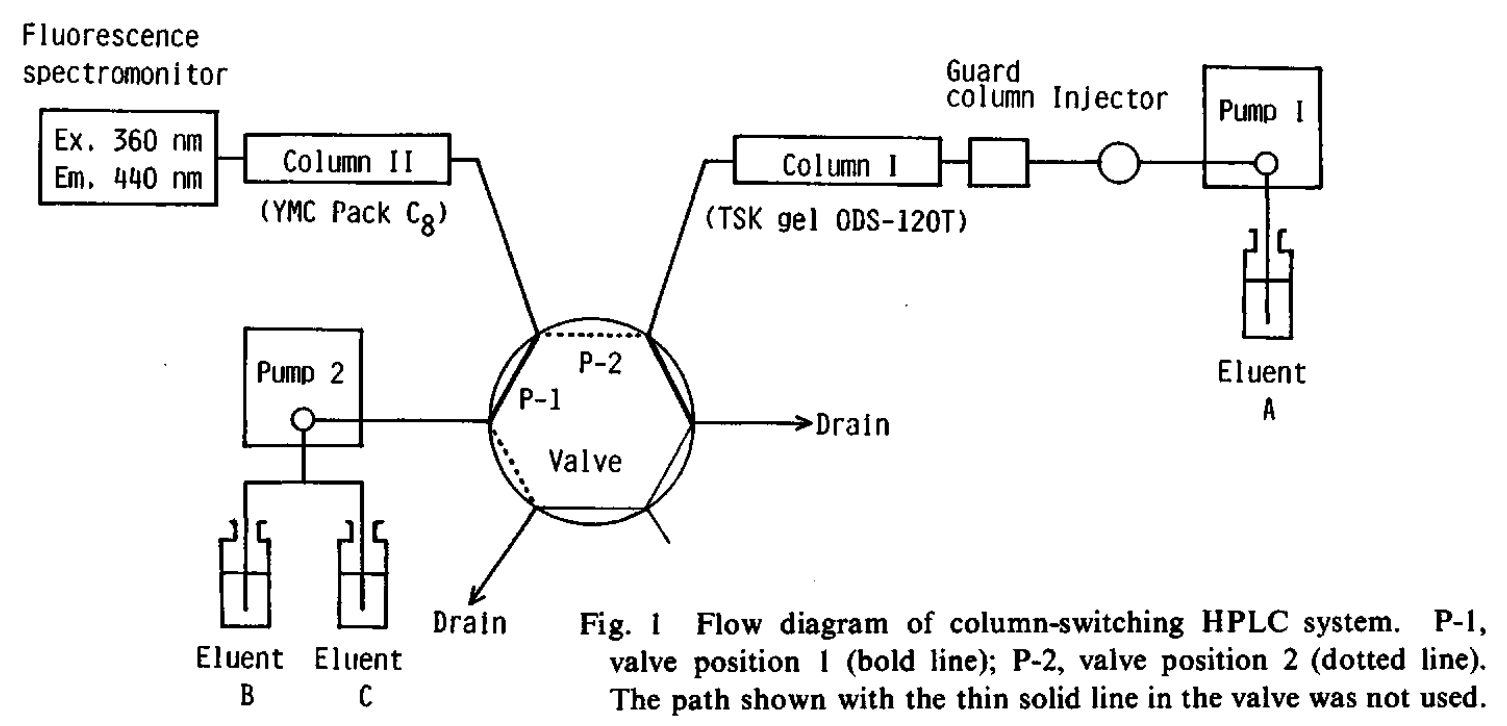

Table 1 Program for controlling the column-switching system

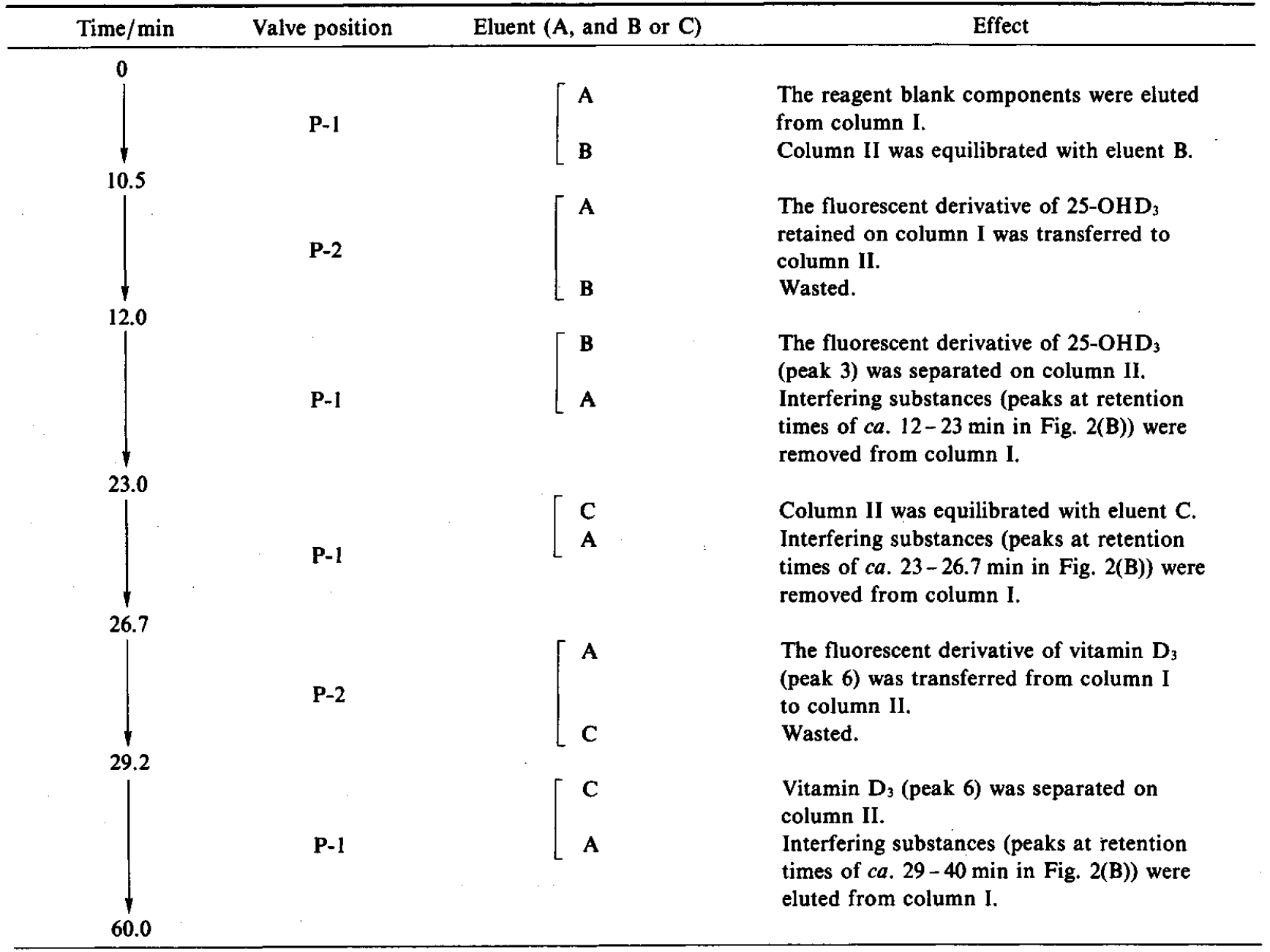


All glassware used for the extraction of vitamin $D_{3}$ and $25-\mathrm{OHD}_{3}$ from sera was rinsed with chloroform and methanol before use. ${ }^{28}$

\section{Apparatus and HPLC conditions}

A flow-diagram of the column-switching HPLC system and a time program of the system controller are shown in Fig. 1 and Table 1, respectively. The system consisted of a preliminary HPLC separation of the DMEQ derivatives of vitamin $\mathrm{D}_{3}$ and $25-\mathrm{OHD}_{3}$ from endogenous substances that came from human and rat sera and an analytical column HPLC for a complete separation of the derivatives.

The column-switching HPLC was performed with a Waters 510 high-pressure pump (pump 1) equipped with a U6K Universal injector valve (10 $\mu$ l loop), a Hitachi L-6200 intelligent pump (pump 2), a Hitachi F1100 fluorescence spectromonitor equipped with a $12 \mu \mathrm{l}$ flow-cell and a Hitachi six-way automatic valve. A TSK gel ODS-120T column (column I; $150 \times 4 \mathrm{~mm}$ i.d.; $5 \mu \mathrm{m}$; Tosoh, Tokyo, Japan), fitted with a guard column (TSK gel ODS-120T, $10 \times 4 \mathrm{~mm}$ i.d.; $5 \mu \mathrm{m}$ ), and a YMC Pack $C_{8}$ column (column II; $150 \times 4 \mathrm{~mm}$ i.d.; 5 $4 \mathrm{~m}$; Yamamura Chemical Labs., Kyoto, Japan) were used as preliminary separation columns and an analytical column, respectively. The columns were maintained at $50 \pm 0.2^{\circ} \mathrm{C}$ with a Shimadzu CTO-6A column oven (Kyoto, Japan). Aqueous 93\%(v/v) methanol (eluent A) and mixtures of acetonitrile- $0.2 \mathrm{M}$ sodium chloride [80:20 (eluent B) and 85:15 (eluent C), v/v] were used as mobile phases. The flow rates of the three eluents were all $1.0 \mathrm{ml} \mathrm{min}^{-1}$. The fluorescence intensity was monitored at $440 \mathrm{~nm}$ (emission) and $360 \mathrm{~nm}$ (excitation).

\section{Preparation of human and rat serum samples}

Human sera were obtained in December from healthy volunteers ( 9 males and 3 females; $22-41$ years old) in our laboratories. Vitamin $\mathrm{D}_{3}$ deficient rats were prepared by the following procedure. Male SpragueDawley rats weighing $40-50 \mathrm{~g}$ ( 3 weeks old) were fed by the rachitogenic diet of Steenbock and Herting 9 for 6 weeks. After a 6-week depletion period, the rat sera were obtained by decapitation.

Lipids including vitamin $\mathrm{D}_{3}$ and $25-\mathrm{OHD}_{3}$ were extracted from serum according to the method of Hollis and Frank. ${ }^{6}$ A human or rat serum sample $(1.0 \mathrm{ml})$ was mixed with saturated ammonium hydrogen sulfate solution $(1.0 \mathrm{ml})$, ethanol $(2.0 \mathrm{ml}), 0.4 \mathrm{M}$ dipotassium hydrogen phosphate $(\mathrm{pH} 10.5)(1.0 \mathrm{ml})$ and acetonitrile $(1.0 \mathrm{ml})$. After vortex-mixing for ca. $1 \mathrm{~min}$, the mixture was centrifuged at $1000 \mathrm{~g}$ for $c a .10 \mathrm{~min}$. The supernatant $(4.0 \mathrm{ml})$ was applied onto a Bond-Elut $\mathrm{C}_{18}$ cartridge. The cartridge was washed successively with water $(5.0 \mathrm{ml})$ and aqueous $70 \%(\mathrm{v} / \mathrm{v})$ methanol $(5.0 \mathrm{ml})$. $A$ fraction containing vitamin $\mathrm{D}_{3}$ and $25-\mathrm{OHD}_{3}$ was eluted with $6.0 \mathrm{ml}$ of acetonitrile at a flow rate of $c a$. $0.4 \mathrm{ml} \mathrm{min}^{-1}$. The eluate was transferred into a screwcapped $10-\mathrm{ml}$ tube and evaporated to dryness under a nitrogen stream.

\section{Derivatization procedure}

To the residue (or a $10 \mu \mathrm{l}$ portion of a standard mixture of vitamin $\mathrm{D}_{3}$ and $25-\mathrm{OHD}_{3}$ ) in the screwcapped vial, $0.2 \mathrm{ml}$ of the DMEQ-CON 3 solution was added. Then the vial was tightly closed and heated at $80^{\circ} \mathrm{C}$ for $80 \mathrm{~min}$. The reaction mixture was diluted with $0.2 \mathrm{ml}$ of methanol and the final solution $(10 \mu \mathrm{l})$ was injected into the HPLC system.

\section{Calibration}

The amounts of vitamin $\mathrm{D}_{3}$ and $25-\mathrm{OHD}_{3}$ were calibrated by means of the standard addition method: $10 \mu$ l of one of standard mixtures of vitamin $\mathrm{D}_{3}(1.3-$ $130 \mathrm{pmol})$ and $25-\mathrm{OHD}_{3}(12.5-250 \mathrm{pmol})$ was added to $1.0 \mathrm{ml}$ of serum. The mixture was allowed to stand at room temperature for $c a$. $60 \mathrm{~min}$, and then treated in the same way as above. The net peak heights of the individual vitamins were plotted against the concentrations of the vitamins.

\section{Results and Discussion}

\section{Derivatization and precolumn HPLC conditions}

Figure 2(A) shows a chromatogram of the DMEQ derivatives of vitamin $\mathrm{D}_{3}$ and $25-\mathrm{OHD}_{3}$, obtained by the preliminary HPLC that used only the guard column, column $I$ and eluent $A$. Vitamin $D_{3}$ and 25$\mathrm{OHD}_{3}$ reacted with DMEQ-CON 3 to give two and four fluorescent products, respectively. The main products for peaks 3 and 6 may be due to the DMEQ carbamic acid esters of 3-hydroxyl group in $25-\mathrm{OHD}_{3}$ and vitamin $D_{3}$, respectively. Peak 5 increased in height for longer reaction times and higher reaction temperatures for the derivatization. This indicates that the peak component is the isomer of vitamin $D_{3}$, provitamin $D_{3}$, which is produced by heating vitamin $D_{3}{ }^{29}$ Peak 4 can be attributed to the DMEQ esters of 25-hydroxyl group (tertiary alcohol) in $25-\mathrm{OHD}_{3}$; tertiary alcohols are less active than secondary alcohols. ${ }^{23}$ Peaks 1 and 2 are probably due to the isomers of the components of peaks 3 and 4, respectively. Peaks 3 and 6, which have the most intense fluorescence in the DMEQ esters of vitamin $\mathrm{D}_{3}$ and $25-\mathrm{OHD}_{3}$, respectively, were employed for the quantification.

Maximum and constant peak heights for peaks 3 and 6 were attained at DMEQ-CON ${ }_{3}$ concentrations greater than $0.9 \mathrm{mM}$ in the reagent solution; $2.0 \mathrm{mM}$ was selected as a sufficient concentration. The derivatization reaction of vitamin $\mathrm{D}_{3}$ and $25-\mathrm{OHD}_{3}$ proceeded more rapidly when the reaction mixture was heated at higher temperatures (Fig. 3). However, at $90^{\circ} \mathrm{C}$, peaks 3 and 6 decreased in height with time. The heights of peaks 3 and 6 reached almost maxima and became constant after heating at $80^{\circ} \mathrm{C}$ for 70 and $60 \mathrm{~min}$, respectively. Thus, heating at $80^{\circ} \mathrm{C}$ for $80 \mathrm{~min}$ was recommended in the procedure.

The derivatization was affected by the solvent used. Of the solvents examined (benzene, toluene, acetone, 
acetonitrile, ethyl acetate, diethyl ether, chloroform, dimethylsulfoxide and $N, N$-dimethylformamide), benzene gave the most intense peaks. Although benzene is prohibited in many laboratories because of its toxicity,

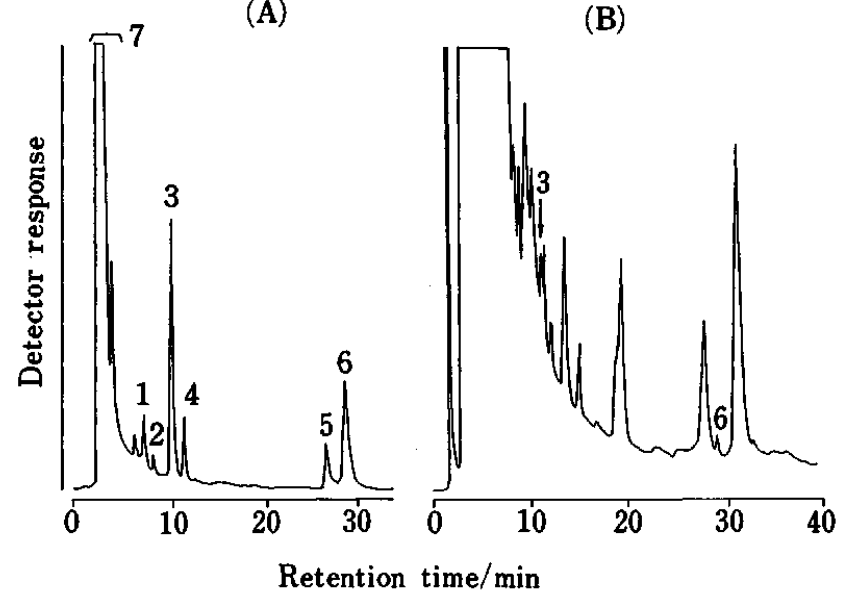

Fig. 2 Chromatograms of the DMEQ derivatives of (A) a standard mixture of vitamin $\mathrm{D}_{3}$ and $25-\mathrm{OH} \mathrm{D}_{3}$ and (B) a lipid extract of normal human serum, obtained by using only the guard column, column I and eluent A. A $10 \mu$ l portion of a standard mixture of the vitamins $\left(65 \mathrm{nmol} \mathrm{ml}^{-1}\right.$ each) was treated according to the derivatization procedure. A $1.0 \mathrm{ml}$ portion of serum was treated according to the serum sample preparation and derivatization procedures. Peaks: 1 and 2, DMEQ esters of 3- and 25-hydroxyl groups in the isomer of 25-OHD $\mathrm{D}_{3}$ (provitamin $\mathrm{D}_{3}$ ), respectively; 3 and 4 , DMEQ esters of 3- and 25-hydroxyl groups in 25-OHD 3 , respectively; 5 , DMEQ ester of the isomer of vitamin $D_{3} ; 6$, DMEQ ester of vitamin $D_{3} ; 7$, reagent blank components; others, endogenous substances in serum. Detector sensitivities: A, 0.2; B, 2.
(A)

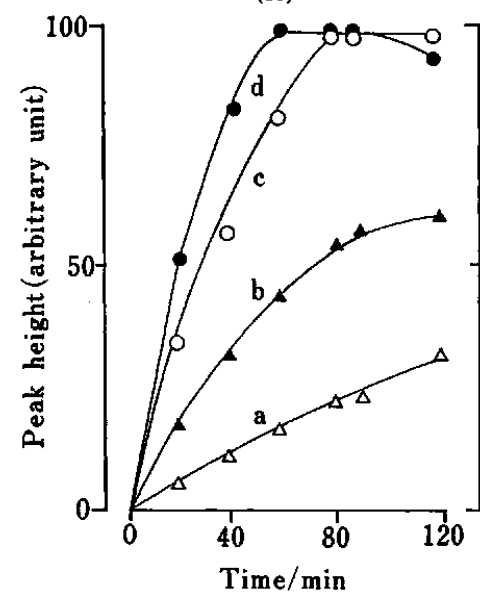

(B)

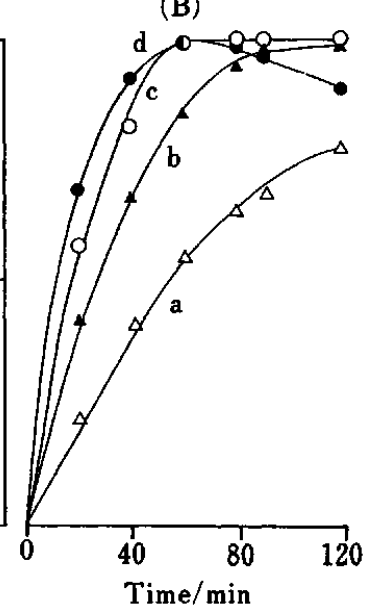

Fig. 3 Effect of reaction time and temperature on the fluorescence derivatization of (A) vitamin $D_{3}$ and (B) 25$\mathrm{OHD}_{3}$. Portions $(10 \mu \mathrm{l})$ of a standard mixture of vitamin $\mathrm{D}_{3}$ and $25-\mathrm{OHD}_{3}\left(65 \mathrm{nmol} \mathrm{m}^{-1}\right.$ each) were treated as in the derivatization procedure at various temperatures for various periods. Temperatures: $\mathrm{a}, 60^{\circ} \mathrm{C} ; \mathrm{b}, 70^{\circ} \mathrm{C} ; \mathrm{c}, 80^{\circ} \mathrm{C} ; \mathrm{d}, 90^{\circ} \mathrm{C}$. we found no other suitable solvent for derivatization of the vitamins.

The within-day precision was examined using a standard mixture of vitamin $\mathrm{D}_{3}$ and $25-\mathrm{OHD}_{3}(20 \mathrm{pmol}$ $10 \mu^{-1}$ each); the relative standard deviations $(n=10)$ for vitamin $\mathrm{D}_{3}$ and $25-\mathrm{OHD}_{3}$ were 2.5 and $4.2 \%$, respectively. The detection limits $(S / N=3)$ for vitamin $\mathrm{D}_{3}$ and $25-\mathrm{OHD}_{3}$ were 15 and $8 \mathrm{fmol}$, respectively, in a $10 \mu \mathrm{l}$ injection volume. This method was much more sensitive than that of the HPLC method with UV detection $^{1-14}$ and comparable in sensitivity to those of the mass fragmentography ${ }^{15}$, the competitive protein binding assays $^{8-14,17-22}$ and the radioimmunoassay. ${ }^{14}$ The relationships between the peak heights and the amounts of vitamin $\mathrm{D}_{3}$ and $25-\mathrm{OHD}_{3}$ were linear up to at least $50 \mathrm{pmol}$ for both compounds in a $10 \mu \mathrm{l}$ injection volume.

Many biogenic substances examined gave no fluorescent derivatives under the described conditions, at a concentration of $10 \mathrm{nmol}$ per $10 \mu \mathrm{l}$; i.e. sugars (Dxylose, D-ribose, 2-deoxy-D-ribose, D-fucose, D-glucose, D-galactose, D-fructose, D-glucosamine, maltose, cellobiose, gentiobiose and lactose), hydroxycarboxylic acids (lactic and malic acids) and seventeen different Lamino acids. Some other vitamin $D_{3}$-related hydroxysteroids gave fluorescent products (Table 2). However, under the conditions of the preliminary HPLC separation, DMEQ derivatives of these steroids have retention times different from those of peaks 3 and 6 in Fig. 1. Accordingly, these substances did not interfere with the determination of vitamin $\mathrm{D}_{3}$ and $25-\mathrm{OHD}_{3}$.

\section{Determination of vitamin $D_{3}$ and $25-O H D_{3}$ in serum}

The solid-phase extraction of lipids including vitamin

Table 2 Retention times for the DMEQ derivatives of vitamin $\mathbf{D}_{\mathbf{3}}$ hydroxysteroids

\begin{tabular}{lc}
\hline \multicolumn{1}{c}{ Compound } & Retention time/min \\
\hline Vitamin $\mathrm{D}_{3}$ & 27.2 \\
& 28.7 \\
$25-\mathrm{OHD}_{3}$ & 8.1 \\
& 9.0 \\
& 11.2 \\
Cholestanol & 12.4 \\
Cholesterol & 57.8 \\
7-Dehydrocholesterol & 42.5 \\
Vitamin D & 36.2 \\
& 25.9 \\
1 $\alpha$-Hydroxyvitamin $\mathrm{D}_{3}$ & 27.2 \\
& 12.9 \\
& 14.5 \\
1 $\alpha, 25$-Dihydroxyvitamin $\mathrm{D}_{3}$ & 17.2 \\
& 5.7 \\
& 6.7 \\
24,25 -Dihydroxyvitamin $\mathrm{D}_{3}$ & 8.6 \\
& 5.0 \\
& 5.5 \\
\hline
\end{tabular}




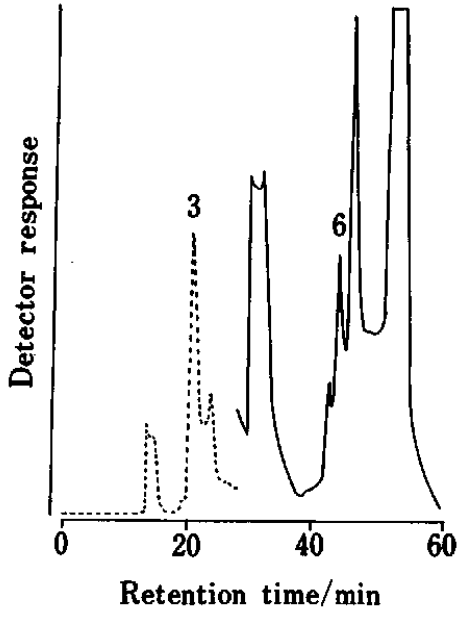

Fig. 4 Chromatogram obtained with a normal human serum. A $1.0 \mathrm{ml}$ portion of serum was treated according to the whole procedure. For peaks 3 and 6, see Fig. 2.

$\mathrm{D}_{3}$ and $25-\mathrm{OHD}_{3}$ from serum ${ }^{6}$ worked well for sample preparation for the derivatization. Without the solidphase extraction, large peaks appeared on the chromatogram and even small peaks for the vitamins could not be detected.

When the lipid extract of human serum was treated according to the derivatization procedure and the reaction mixture was subjected to an HPLC using only the guard column and column I, large peaks due to endogenous substances other than vitamin $D_{3}$ and 25$\mathrm{OHD}_{3}$ in human serum appeared on the chromatogram (Fig. 2(B)) and interfered with the determination of the vitamins. Thus, a column-switching HPLC was introduced to diminish the interfering substances.

Figure 4 shows a chromatogram obtained with normal human serum. Peaks 3 and 6 in Fig. 4 were identified as the DMEQ derivatives of vitamin $\mathrm{D}_{3}$ and $25-\mathrm{OHD}_{3}$, respectively, on the basis of their retention times and fluorescence excitation and emission spectra compared with those of the standard compounds, and co-chromatography of the standards and sera with aqueous $50-100 \%$ methanol as mobile phase. Further evidence was provided when a serum sample from a vitamin- $D_{3}$-deficient rat was treated as in the procedure; no peaks were observed at the retention times for peaks 3 and 6 (Fig. 5(B)), though peaks 3 and 6 were observed in the chromatogram of normal rat serum (Fig. 5(A)), the pattern of which was quite similar to that of the chromatogram given by human serum (Fig. 4).

Linear relationships were observed between the peak heights and the amounts of vitamin $\mathrm{D}_{3}$ and $25-\mathrm{OHD}_{3}$ (up to $500 \mathrm{pmol}$ each) added to $1.0 \mathrm{ml}$ of serum.

The within-day precision was determined using a normal human serum containing vitamin $D_{3}$ and 25$\mathrm{OHD}_{3}$ at mean concentrations of 5.21 and $45.0 \mathrm{pmol}$ $\mathrm{ml}^{-1}$, respectively. The relative standard deviations
(A)

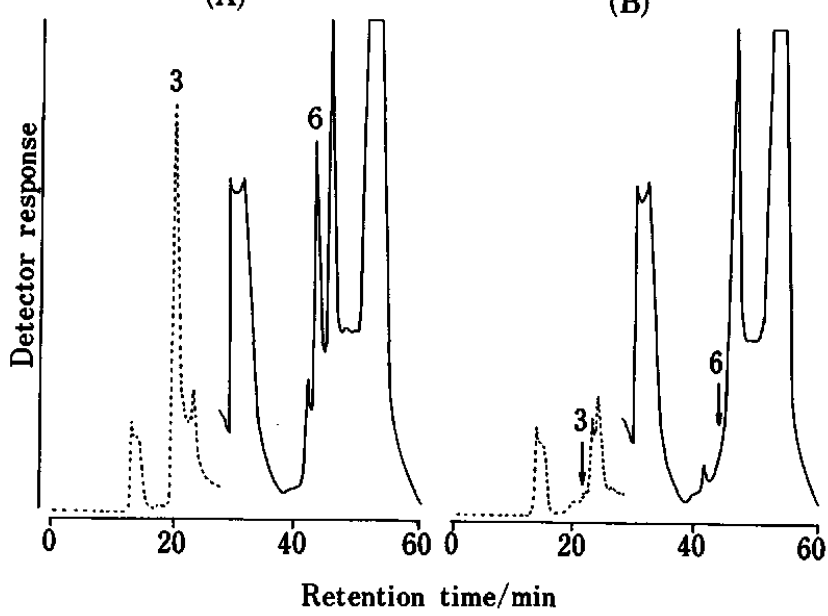

Fig. 5 Chromatograms obtained with sera from (A) normal and (B) vitamin $D_{3}$ defficient rats. A $1.0 \mathrm{ml}$ portion of rat serum was treated according to the whole procedure. For peaks 3 and 6, see Fig. 2. Arrows 3 and 6 correspond to the retention times for peaks 3 and 6, respectively. Detector sensitivities: $\cdots \ldots, 1 ;-, 10$.

Table 3 Concentrations of $25-\mathrm{OHD}_{3}$ and $\mathrm{D}_{3}$ in normal human sera

\begin{tabular}{ccccc}
\hline Age & Sex $^{\mathrm{a}}$ & $\begin{array}{c}25-\mathrm{OHD}_{3} / \\
\mathrm{ng}\left(\mathrm{pmol} \mathrm{ml}^{-1}\right.\end{array}$ & $\begin{array}{c}\mathrm{D}_{3} / \\
\mathrm{ng}(\mathrm{pmol}) \mathrm{ml}^{-1}\end{array}$ \\
\hline 41 & $\mathrm{M}$ & $21.0(52.4)$ & $1.26(3.28)$ \\
38 & $\mathrm{M}$ & $19.0(47.4)$ & $2.10(5.46)$ \\
31 & $\mathrm{M}$ & $6.2(15.4)$ & $3.49(9.07)$ \\
25 & $\mathrm{M}$ & $8.7(21.7)$ & $1.18(3.07)$ \\
25 & $\mathrm{M}$ & $17.3(43.2)$ & $4.55(11.83)$ \\
24 & $\mathrm{M}$ & $17.3(43.2)$ & $1.14(2.96)$ \\
23 & $\mathrm{M}$ & $10.3(25.7)$ & $1.14(2.96)$ \\
22 & $\mathrm{M}$ & $12.4(30.9)$ & $1.34(3.48)$ \\
22 & $\mathrm{M}$ & $13.6(33.9)$ & $1.30(3.38)$ \\
21 & $\mathrm{M}$ & $28.0(69.9)$ & $1.75(4.55)$ \\
26 & $\mathrm{~F}$ & $15.7(39.2)$ & $0.37(0.96)$ \\
23 & $\mathrm{~F}$ & $10.7(26.7)$ & $0.90(2.34)$ \\
22 & $\mathrm{~F}$ & $10.1(25.2)$ & $1.20(3.12)$ \\
Mean & & $14.6(36.5)$ & $1.67(4.34)$ \\
Standard & & & $1.09(2.84)$ \\
deviation & $5.7(14.2)$ & & \\
\hline
\end{tabular}

a. $M$, male; F, female.

were 9.4 and $6.5 \%$ for vitamin $\mathrm{D}_{3}$ and $25-\mathrm{OHD}_{3}$, respectively $(n=10)$. The precision almost equaled those of the other methods. ${ }^{1-22}$ Although we tried to find an internal standard substance suitable both for the column-switching HPLC separation and the fluorescence derivatization to improve the precision, we could not find such a substance. The recoveries of vitamin $\mathrm{D}_{3}(15.4 \mathrm{pmol})$ and $25-\mathrm{OHD}_{3}(145 \mathrm{pmol})$ added to human serum $(1.0 \mathrm{ml})$ were $53.8 \pm 4.9$ and $76.9 \pm 7.2 \%$ (mean \pm standard deviation, $n=8$ ), respectively. 
Table 4 Concentrations of $25-\mathrm{OHD}_{3}$ and $\mathrm{D}_{3}$ in rat sera

\begin{tabular}{ccc} 
Sample & $\begin{array}{c}25-\mathrm{OHD}_{3} / \\
\mathrm{ng}(\mathrm{pmol}) \mathrm{ml}^{-1}\end{array}$ & $\begin{array}{c}\mathrm{D}_{3} / \\
\mathrm{ng}(\mathrm{pmol}) \mathrm{ml}^{-1}\end{array}$ \\
\hline 1 & $54.1(135)$ & $10.2(26.0)$ \\
2 & $43.1(107)$ & $6.41(16.6)$ \\
3 & $85.1(221)$ & $8.90(23.1)$ \\
4 & $53.5(113)$ & $7.41(19.2)$ \\
5 & $59.5(148)$ & $6.62(17.1)$ \\
6 & $31.0(77)$ & $7.43(19.2)$ \\
Mean & $54.4(137)$ & $7.82(20.2)$ \\
Standard & $16.6(44.2)$ & $1.24(3.08)$ \\
deviation & & \\
\hline
\end{tabular}

The concentrations of vitamin $\mathrm{D}_{3}$ and $25-\mathrm{OHD}_{3}$ in normal human serum are given in Table 3 . The concentrations of vitamin $D_{3}$ in serum were in good agreement with those obtained by Jones ${ }^{8}$ and by Shepard et al. ${ }^{9}$, although the values were slightly lower than those given by Aksnes ${ }^{10}$ and Seamark et al..$^{15}$ The mean value of $25-\mathrm{OHD}_{3}$ obtained by this study was similar to those reported by other workers. ${ }^{1-22}$

The concentrations of the vitamins in normal rat serum determined by the method are shown in Table 4 . The levels of the vitamins in rat serum were $c a$. 3-5 times higher than those in human serum.

This study provided the first HPLC method with fluorescence detection for the simultaneous determination of vitamin $\mathrm{D}_{3}$ and $25-\mathrm{OHD}_{3}$ in human and rat sera. The method has adequate sensitivity to measure the vitamins in $1.0 \mathrm{ml}$ of normal human and rat sera. The method is relatively more simple and rapid than the other methods are. The method should therefore be useful for physiological and pharmacological investigation of vitamins.

The authors express their gratitude to Chugai Pharmaceutical Co. (Tokyo, Japan) for the financial support in this study.

\section{References}

1. D. J. H. Trafford, D. A. Seamark, H. Turnbull and H. L. J. Makin, J. Chromatogr., 226, 351 (1981).

2. E. A. Johl and P. C. Schaefer, J. Liq. Chromatogr., 4, 2023 (1981).

3. J. T. Dabek, M. Harkonen, $O$. Wahlroos and $H$. Adlercreutz, Clin. Chem., 27, 1346 (1981).

4. H. Turnbull, D. J. H. Trafford and H. L. J. Makin,
Clin. Chim. Acta, 120, 65 (1982).

5. J. C. K. Loo and R. Brien, Res. Commun. Chem. Pathol. Pharmacol., 41, 139 (1983).

6. B. W. Hollis and N. E. Frank, J. Chromatogr., 343, 43 (1985).

7. R. L. G. Norris, M. J. Thomas and P. W. Craswell, J. Chromatogr., 381, 53 (1986).

8. G. Jones, Clin. Chem., 24, 287 (1978).

9. H. Steenbock and D. C. Herting, J. Nutr., 57, 449 (1955).

10. L. Aksnes, Clin. Chim. Acta, 104, 133 (1980).

11. M. Imawari, K. Kozawa, T. Yoshida and T. Osuga, Clin. Chim. Acta, 124, 63 (1982).

12. T. Kobayashi and T. Okano, J. Nutr. Sci. Vitaminol., 29, 271 (1983).

13. S. Yamamoto and N. Hasegawa, Clin. Chem., 31, 1919 (1985).

14. R. Bouillon, E. Van Herck, I. Jans, B. Kengstan, H. Van Baelen and P. De Moor, Clin. Chem., 30, 1731 (1984).

15. D. A. Seamark, D. J. H. Trafford and H. L. J. Makin, Clin. Chim. Acta, 106, 51 (1980).

16. E. E. Delvin, M. Dussault and F. M. Gloviex, Clin. Biochem., 13, 106 (1980).

17. E. Keck and H. L. Kruskemper, J. Clin. Chem. Clin. Biochem., 19, 1043 (1981).

18. M. T. Parviainen, K. E. Savolainen, E. M. Alhava and P. H. Maepaa, Ann. Clin. Res., 13, 26 (1981).

19. M. J. M. Jongen, W. J. F. Van der Vijigh, H. J. J. Willems, J. C. Netelenbos and P. Lips, Clin. Chem., 27, 1757 (1981).

20. M. T. Parviainen, K. E. Savolainen,P. M. Korhonen, E. M. Alhava and J. K. Visakorpi, Clin. Chim. Acta, 114, 233 (1981).

21. P. C. Kao and D. W. Heser, Clin. Chem., 39, 56 (1984).

22. G. S. Shephard, S. M. Carlini, C. Hanekom and D. Labadarios, Clin. Chim. Acta, 167, 231 (1987).

23. M. Yamaguchi, T. Iwata, M. Nakamura and $Y$. Ohkura, Anal. Chim. Acta, 193, 209 (1987).

24. T. Iwata, M. Yamaguchi and M. Nakamura, J. Chromatogr., 421, 43 (1987).

25. T. Iwata, M. Yamaguchi, $M$. Nakamura and $Y$. Ohkura, Jpn. J. Clin. Chem., 18, 100 (1989).

26. T. Iwata, H. Hanazono, M. Yamaguchi, M. Nakamura and Y. Ohkura, J. Chromatogr., 491, 404 (1989).

27. T. Iwata, H. Hanazono, M. Yamaguchi, M. Nakamura and Y. Ohkura, Anal. Sci., 5, 671 (1989).

28. R. M. Shepard, R. L. Horst, A. J. Hamstra and H. F. Deluca, Biochem. J., 182, 55 (1979).

29. J. A. K. Buisman, K. H. Hanewald, F. J. Mulder, J. R. Roborgh and K. J. Keuning, J. Pharm. Sci., 57, 1326 (1968).

(Received January 26, 1990)

(Accepted February 26, 1990) 